\title{
Micro-prudentiality and financial stability
}

\author{
Cristian Ionescu, PhD Candidate, Academy of Economic Studies, Romania
}

\begin{abstract}
Given the high degree of importance of issues related to financial instability in modern economies, (financial, economic and social aspects), it is necessary the analysis of the microeconomic components that determine macroeconomic fluctuations, resulting in the visible financial instability. Thus, this paper aims to analyze the following aspects: financial fragility, as a measure of financial instability at the microeconomic level; micro-prudential regulation; microeconomic reform measures, which addresses problems related to capital, liquidity, risk management and supervision and market discipline. All these are integrated into the international Basel III framework of the Bank of International Settlements Regulations. In addition, the manner and the time of Basel III implementation of the capital and liquidity-related measures is very important. In addition, the paper aims to analyze the inter-connections and the compromises between capital and liquidity, trying to understand how the two are connected.
\end{abstract}

\section{Keywords:}

financial stability, micro-prudential regulation, Basel III, capital, liquidity, risk

\section{JEL Codes: D04, D53, G01, G21, G32}

\section{Financial fragility, as a measure of financial instability}

There is a link between asset price bubbles and financial fragility. In the middle of the bubbles build-up are the principal-agent conflicts, because bank managers' upside-risk payoffs increase in risk, while limited financial liability involves restricted downside-risk losses. Through intermediation, investors place borrowed funds into risky assets, which stimulates the borrowers to bid-up asset prices above their fundamental values, finally leading to a bubble, which are propagated by investors' expectations of higher future credit availability and credit volatility, since this allows higher asset returns via risk transfer ${ }^{1}$.

Contagion also implies direct bank linkages, where the borrowing arrangements between banks can lead to domino effects if there is at least one systemic important bank that is not capable of meeting its obligations, sometimes due to depositors run (withdrawing massive funds from the bank). Thus, the "rational herding" involves negative externalities.

Autocorrelations between bank failures means concentrations of failures (contagion). The unusual bank stock price behavior due to "bad news" regarding the banks' performance shows that contagion is also due to depositors' behavior as a response to bad news.

Regarding the definition of financial fragility, there may be used two approaches (both at firm and aggregate level): a) reduced bank profitability and b) increased default probability. One single component do not necessary implies fragility; lower profitability may be a consequence of recession and high risk taking, leading to defaults, but without affecting stability. But both components, considered in the same time, do imply financial fragility.

\footnotetext{
${ }^{1}$ Davis P.; Karim D. (2009), Macro-prudential regulation - the missing policy pillar, The 6th Euro-frame Conference on Economic Policy Issues in the European Union
} 
Risk is another important issue. Holding assets as claims against other borrowers, financial institutions generate complex interconnections of risk exposures; thus, relative asset and liability values, credit availability and asset prices become interdependent. These externalities are shocks to financial systems that, if amplified, lead to spillovers onto the balance sheets. One solution to the problem of the interlocking balance sheets system in order to solve for asset prices which depend on the creditworthiness of other financial institutions is that each claim should uniquely priced in terms of parameters describing the underlying financial system (current prices of underlying assets, debt levels and structure, and the profile of balance sheet inter-linkages) ${ }^{2}$.

Regarding the regulators' incentives, the regulator's response to instability is conditioned on the ex-ante probability of asset price collapse; there are two possible situations: if the probability is high, the remedial actions are optimal; if the probability is low, the regulator is forbearing to instability. Principal-agent and political motives are two reasons why regulators show forbearance, instead of implementing prompt corrective action. Regulators that seek the maximizing of the utility consider forbearance as a strategy where taxpayers bear the costs.

Regarding the systemic risk, the contagion via market price changes in the context of mark to market (where financial institutions' active balance sheet management generates a positive relation of leverage and balance sheet size) is also important.

Regarding liquidity, financial institutions boost liquidity in times of boom, aiming to expansion, while a shock to asset prices led to contractions. There are amplifying mechanisms of liquidity shocks, which lead to the following effects: a) borrowers' balance sheet effects (determining a loss spiral and margin spiral); b) a lending channel effect (determining hoarding of liquidity); c) runs on institutions and markets; d) network effects.

\section{Micro-prudential, firm-specific reform measures}

The micro-prudential reform measures imply stronger capital and liquidity regulation (but not forgetting a more general background that includes improvements in supervision, risk management and governance, a greater transparency and disclosure $)^{3}$.

One major international institution that manages the micro-prudential reform measures is the Basel Committee on Banking Supervision, using the Basel framework.

\subsection{Capital}

The global banking system, before a financial crisis, implies insufficient level of high quality capital. Therefore, there are many banks that rebuild their common equity capital bases in the crisis, not before the crisis, where it is most difficult to do so. There are also differences in defining the capital between jurisdictions and the lack of disclosure enables markets to assess and compare the quality of capital across institutions.

\subsubsection{Proposals Regarding Capital}

Basel II regulations considered that the overall level of capital in the system is sufficient, but it is necessary to increase the risk sensitivity in order to promote better risk management and in order to reduce regulatory arbitrage. The main component of Basel II, Pillar 1, was in the definition of risk-weighted assets. Regulators realized the need to refine the definition of the capital components. But the financial crisis that started in 2008 shown that there is a need redefining the capital (components of Tier 1 capital were unable to absorb losses).Therefore,

\footnotetext{
2 idem

${ }^{3}$ Basel Committee on Banking Supervision (2010), The Basel Committee's response to the financial crisis: report to the G20, Bank for International Settlements
} 
the Tier 1 capital should include common shares and retained earnings, and the remaining part should include instruments that: a) are subordinated, b) have fully discretionary noncumulative dividends or coupons, c) have no incentive to redeem. Moreover, the risk sensitivity assumptions in the case of many transaction types (like securitizations and derivatives) were insufficient during the financial crises. The Basel III regulations underlined the necessity of increasing the quality, quantity and international consistency of the capital base, and increasing the capital requirements for certain types of transactions. It is also necessary the introduction of a non-risk based leverage ratio, in order to diminish the build up of leverage in the financial system. Basel III also intends to reduce the pro-cyclicality of the Basel II framework.

\subsubsection{Capital Base}

Basel III implies that the regulatory adjustments are applied either to a combination of Tier 1 and Tier 2 capital or only to Tier 1 capital. Therefore, Tier 1 capital is defined as items that can absorb losses, while Tier 2 is defined as capital that can be used to offset losses. Tier 3 capital, which offsets the market risk in the Basel II framework, will be entirely eliminated.

Therefore, there is a greater focus on common equity, the highest quality component of a bank's capital, while adopting a stricter definition of common equity, requiring regulatory capital deductions to be taken from common equity rather than from Tier 1 or Tier 2 capital as in Basel II. As a result, it will be impossible for banks to have strong Tier 1 capital ratios with limited common equity net of regulatory deductions.

Thus, higher quality capital means more loss-absorbing capacity, which leads to stronger banks, permitting them to better resist to high stress periods (and even financial instability periods).

\subsection{Risk Coverage}

In addition to tightening the definition of capital (raising the quality and level of the capital base), Basel III proposes to increase capital requirements for certain types of transactions. It is necessary to make sure that all risks are included in the capital framework. During a financial crisis, it is possible that many of the risks may not be properly covered in the riskbased regime (for example, there may be banks with great volumes of complex, illiquid credit products, but with no adequate capital amount to support the risk). In addition, not including the main on-balance sheet risks and off-balance sheet risks and the derivative related exposures may amplify a financial crisis.

Therefore, Basel III is introducing a set of enhancements to the capital framework that strengthens the minimum capital requirements for complex securitizations (higher risk weights for re-securitization exposures in order to better reflect the risk of the financial products, raising the capital requirements for certain exposures to off-balance sheet vehicles, the requirement that banks conduct more rigorous credit analyses of externally rated securitization exposures) ${ }^{4}$.

Basel III is also increasing the regulatory capital requirements and is improving risk management for counterparty credit risk (due to deterioration in the credit quality of counterparties that is an important source of credit-related loss). These include: a) using stressed inputs to calculate the capital requirement for counterparty credit default risk; b) new capital requirements, in order to protect banks against the risk of reducing the counterparties' credit quality.

\footnotetext{
${ }^{4}$ ibidem
} 


\subsection{Leverage Ratio}

Another essential cause for a financial crisis may be a high leverage in the banking system. In order to reduce the build-up of leverage, Basel III introduces risk-based requirements. The design for the leverage ratio involves: a) regarding the off-balance-sheet items, it will be used a uniform credit conversion factor, with a $10 \%$ credit conversion factor for unconditionally cancellable off-balance-sheet commitments; b) regarding the derivatives, it will be introduced a new measure of potential future exposure based on standardized factors. Therefore, derivatives will be converted in a consistent manner to a "loan equivalent" amount.

\subsection{Counter-Cyclical Capital Buffers}

Financial crises involve pro-cyclical amplification of financial shocks. The Basel III countercyclical capital buffer is designed to achieve four objectives: a) reducing/ eliminating cyclicality; b) promoting forward looking provisioning; c) conserving capital for use in periods of stress; d) protecting the banking system from excessive credit growth.

The capital conservation buffer will absorb losses during a period of severe stress while the countercyclical buffer will increase the capital conservation range during periods of excess credit growth.

The buffer will be "deployed when excess aggregate credit growth is judged to be associated with a build-up of system-wide risk to ensure the banking system has a buffer of capital to protect it against future potential losses." Thus, the countercyclical capital buffers will be deployed in a specific jurisdiction on an infrequent basis, "perhaps as infrequently as once every 10 to 20 years." National bank regulators will inform banks in advance of their judgment of any "buffer add-on", giving banks sufficient time in order to achieve the additional capital requirements, while the decreasing a buffer will take place immediately, so that the supply of credit shouldn't be constrained by the regulatory capital requirements.

Therefore, internationally banks will take into consideration the geographic location of their credit exposures and compute the buffer add-on for each credit exposure depending on the buffer-in effect from the jurisdiction of the exposures (the buffer will be equal to a weighted average of the buffer add-ons from the jurisdictions of the exposures).

In order to give assistance to national banking regulators in every jurisdiction, Basel III uses a methodology in order to provide a common starting reference point, transforming the gap between the aggregate private sector credit and gross domestic product ratio into a buffer add-on (a zero add-on means a credit/gross domestic product ratio near or below the longterm trend; a positive add-on means a credit/gross domestic product ratio that is greater than the long-term trend, where the specific amount represents the excessive credit growth). Although the national authorities will not mechanistically react depending on the credit/gross domestic product ratio, they will take it into consideration when applying the judgment in the setting of the buffer in the jurisdictions (also using the best information available in order to reduce the creation and accumulation of the system-wide risk).

Basel III considers that a countercyclical buffer within a range of [0\%, 2.5\%] of common equity or other fully loss absorbing capital will be implemented according to national circumstances, in order to achieve the macro-prudential objective of protecting the banking sector from excessive aggregate credit growth that may lead to a system-wide build-up of risk. 


\section{Liquidity}

Strong capital requirements are a necessary for the banking sector stability (and for the overall financial stability), but they are not sufficient. It is also necessary the introduction of stronger bank liquidity that should reduce both individual level and system wide stress.

Basel III involves some common metrics as minimum types of information that supervisors should use in monitoring the liquidity risk of the financial entities.

Liquidity risk comes from the mismatch between the timings of cash inflows and cash outflows. This is an important issue, especially for the banking sector, where one of the most critical functions of modern banking system is the reallocation of financial resources from the liquid sectors to the illiquid sectors. This framework involves two consequences: a) the banking sector is exposed to a maturity mismatch (the term on which liquid units invest their liquidity is shorter than the term on which illiquid units borrow; the reallocation of the financial resources from one sector to the other involves mismatch of maturities for the banking system in the form of liquidity risk); b) the banking industry is leveraged (banks borrow money from liquid sectors and lend the money to illiquid sectors; therefore, a high leverage increases the impact of the liquidity problem, both on an individual and a system levels.

But regulators cannot remove the mismatch liquidity risk from the system. Instead, the regulators try to force the banks to build liquid reserves to ensure withstanding the cash imbalances in the case of a financial crisis, until the situation returns to normality.

\subsection{The New Liquidity Requirements}

Basel III introduces two new ratios (Liquidity Coverage Ratio and Net Stable Funding Ratio); these indicate the minimum maintained liquidity, in order to withstand cash obligations in the situation of a financial crisis or financial stress.

The Liquidity Coverage Ratio covers the short-time time horizon and it ensures that every bank have enough liquid resources in order to fulfill the cash obligations in the case of a severe financial stress. The Liquidity Coverage Ratio is calculated as following:

$$
\frac{\text { Stock of High - Quality Liquid Assets } 2100 \%}{\text { Not Cush Oulfows uevr a } 30-\text { day Forkud }}
$$

The Net Stable Funding Ratio covers the medium-term time horizon and it ensures the structural balance between maturities of a bank's assets and liabilities. It aims to prevent banks from exposing themselves to extreme maturity transformation risks by funding medium and long-term assets with very short-term liabilities ${ }^{5}$ (which may lead to a systemic liquidity shortage when major short-term liquidity channels severely drop down).

The Net Stable Funding Ratio requires banks to have enough funding for at least one year in order to compensate all cash needs expected to occur. The Net Stable Funding Ratio is calculated as following:

$$
\frac{\text { Avallable Amount of Stable Funding } \geq 100 \%}{\text { Reyulred Antuwh of Stable Furuling }}
$$

Available Amount of Stable Funding includes cash, equity and liabilities that remain within the bank for at least one year (because of the long contractual maturity or because of their rigidity even if the contractual maturity falls within that year. Required Amount of Stable

\footnotetext{
${ }^{5}$. Barua R.; Battaglia F.; Jagannathan R.; Mendis J.; Onorato M. (2010), Basel III: What's New? Business and Technological Challenges
} 
Funding includes the amount of assets that are not reimbursed for at least one year (and which need to be funded for at least one year) and the cash outflows that occur beyond one year (due to the contingent liabilities).

There are some instruments that require a 100\% Stable Funding: a) securitize-able assets; b) assets from securitizations; c) securities issued by banks or other financial institutions; d) any security with rating lower than A-.

In addition to the Liquidity Coverage Ratio and Net Stable Funding Ratio, Basel III includes a set of monitoring tools as minimum types of information that supervisors should use in their monitoring activity: a) contractual maturity mismatch; b) concentration of funding; c) market-related monitoring tools (asset prices and liquidity, CDS spreads, equity prices).

\section{Risk management and supervision}

Stronger capital and liquidity standards must be accompanied by better risk management and supervision, especially in an environment characterized by a continuously rapid financial innovation.

Therefore, Basel III in regard to the supervisory process emphasizes the importance of several weaknesses revealed in the banks' risk management processes during financial crisis periods. The solutions taken into consideration include: a) firm-wide governance and risk management; b) capturing the risk of off-balance sheet exposures and securitization activities; c) managing risk concentrations; d) providing incentives for banks to better manage risk and returns over the long term; e) sound compensation practices ${ }^{6}$.

\section{Market discipline}

During a financial crisis, it is often possible that the disclosures provided by the banks about their risk exposures and regulatory capital bases to be deficient and inconsistent. In addition, there is insufficient information regarding the components of capital, making difficult an accurate assessment of the capital quality. Therefore, in order to improve transparency and market discipline, Basel III is requiring that banks disclose all elements of the regulatory capital base, the deductions applied and a full reconciliation to the financial accounts ${ }^{7}$. Thus, Basel III aims to ensure that banks disclose clear, comprehensive and timely information regarding the remuneration practices, in order to promote a more effective market discipline. Consistency of disclosure requirements should contribute to a higher convergence of practices.

\section{Implementation Timelines of Basel III}

Table 1 illustrates the implementation deadlines of the capital reforms and of the introduction of a global liquidity standard, which will improve the global financial system.

\footnotetext{
${ }^{6}$ Basel Committee on Banking Supervision (2010), The Basel Committee's response to the financial crisis: report to the G20, Bank for International Settlements

${ }^{7}$ ibidem
} 
Table 1. Phase-in arrangements (shading indicates transition period) (all dates are as 1 January)

\begin{tabular}{|c|c|c|c|c|c|c|c|c|c|}
\hline & 2011 & 2012 & 2013 & 2014 & 2015 & 2016 & 2017 & 2018 & $\begin{array}{c}\text { As of } \\
1 \text { January } \\
2019\end{array}$ \\
\hline Leverage Ratio & \multicolumn{2}{|c|}{ Superisoxy monitoring } & \multicolumn{4}{|c|}{$\begin{array}{l}\text { Parallet run } \\
11 \text { an } 2013 \text { - } 1 \text { Jan } 2017 \\
\text { Disclosure starts } 1 \text { lan } 2015\end{array}$} & & Mingation to & \\
\hline Minimum Common Equity Capital Ratio & & & $3.5 \%$ & $4.0 \%$ & $4.5 \%$ & $4.5 \%$ & $4.5 \%$ & $4.5 \%$ & $4.5 \%$ \\
\hline Capital Conservation Buffer & & & & & & $0.625 \%$ & $1.25 \%$ & $1.875 \%$ & $2.50 \%$ \\
\hline $\begin{array}{l}\text { Minimum common equity plus capital } \\
\text { conservation buffer }\end{array}$ & & & $3.5 \%$ & $4.0 \%$ & $4.5 \%$ & $5.125 \%$ & $5.75 \%$ & $6.375 \%$ & $7.0 \%$ \\
\hline $\begin{array}{l}\text { Phase-in of deductions from CET1 } \\
\text { (including amounts exceeding the limit } \\
\text { for DTAs, MSRs and financials) }\end{array}$ & & & & $20 \%$ & $40 \%$ & $60 \%$ & $80 \%$ & $100 \%$ & $100 \%$ \\
\hline Minimum Tier 1 Capital & & & $4.5 \%$ & $5.5 \%$ & $6.0 \%$ & $6.0 \%$ & $6.0 \%$ & $6.0 \%$ & $6.0 \%$ \\
\hline Minimum Total Capital & & & $8.0 \%$ & $8.0 \%$ & $8.0 \%$ & $8.0 \%$ & $8.0 \%$ & $8.0 \%$ & $8.0 \%$ \\
\hline $\begin{array}{l}\text { Minimum Total Capital plus } \\
\text { conservation buffer }\end{array}$ & & & $8.0 \%$ & $8.0 \%$ & $8.0 \%$ & $8.625 \%$ & $9.25 \%$ & $9.875 \%$ & $10.5 \%$ \\
\hline $\begin{array}{l}\text { Capital instruments that no longer qualify } \\
\text { as non-core Tier } 1 \text { capital or Tier } 2 \text { capital }\end{array}$ & & & \multicolumn{7}{|c|}{ Phased out over 10 year horizon beginning 2013} \\
\hline Liquidity coverage ratio & $\begin{array}{c}\text { Observastion } \\
\text { Pereid } \\
\text { begins } \\
\end{array}$ & & & & $\begin{array}{l}\text { Introduce } \\
\text { Minimum } \\
\text { Standard }\end{array}$ & & & & \\
\hline Net stable funding ratio & & $\begin{array}{c}\text { observation } \\
\text { Period } \\
\text { begins }\end{array}$ & & & & & & $\begin{array}{l}\text { Introduce } \\
\text { Minimum } \\
\text { Standard }\end{array}$ & \\
\hline
\end{tabular}

(Source: Basel Committee on Banking Supervision (2010), The Basel Committee's response to the financial crisis: report to the G20, Bank for International Settlements)

\section{Business impact and challenges: exploring the interplay between Liquidity and Capital}

\subsection{Exploring Interconnections and Trade-Offs between Capital and Liquidity}

Over the last 30 years, there were some major changes in the financial sector: the banking sector has become more complex; trading and structured finance has become more spread out and complex; the corporate structure of banks has also become more complex. All these created a more difficult risk measurement and management. Although risk management is now seen as a primary component of banks, the reporting tools and risk management functions (such as stress testing) have not been entirely integrated across departments. Banks maintained the decentralized IT functions that support finance, treasury, business lines and risk management, but they haven't re-conciliate the data across departments, which created a culture of risk management that failed to view risk in a holistic way. A proper effective risk management system should take a top-down approach to risk measurement and reporting, viewing and managing the interconnections between risk factors at a high level, such that their potential impact on the balance sheet can be properly accounted.

This is the manner that Basel III is addressing liquidity risk, recognizing the connections between leverage, capital and liquidity. Basel II implies stress testing of liquidity and capital separately.

But a robust and truly risk-based framework should take into consideration the interdependence between the capital risk and liquidity risk.

\subsection{Misunderstanding how liquidity risk and capital are connected}

Although capital mitigates unexpected losses, it does not mitigate cash flow imbalances (liquidity risk). Therefore, if a financial institution faces a liquidity problem, then it needs cash (not capital). If in the case of a liquidity problem the bank uses its reserves to protect itself against liquidity risk and to absorb losses and meet obligations, the value of the bank 
and of the capital will decrease, since the bank will be perceived as "riskier". This way of seeing things implies that liquidity risk and capital are inextricably linked.

But Basel III, using liquidity coverage ratio and net stable funding ratio as primary responses to liquidity risk, do not recognize an inextricably link.

Using a holistic risk management framework, each bank would decide the size of the liquidity buffer and the proper time horizon, based on a proper assessment of the bank's overall risk appetite. From a best practice governance perspective, if a financial institution has more than the needed amount of liquid assets then the part of the liquidity buffer that is not needed, it has an opportunity cost associated with it. But if the financial institution has less than necessary to maintain stability, then the bank risks bankruptcy.

\section{References:}

1. Barua R.; Battaglia F.; Jagannathan R.; Mendis J.; Onorato M. (2010), Basel III: What's New? Business and Technological Challenges

2. Basel Committee on Banking Supervision (2011), Marrying the macro and micro-prudential dimensions of financial stability, Bank for International Settlements

3. Basel Committee on Banking Supervision (2010), The Basel Committee's response to the financial crisis: report to the G20, Bank for International Settlements

4. Basel Committee on Banking Supervision (2010), Basel III: International framework for liquidity risk measurement, standards and monitoring, Bank for International Settlements

5. Basel Committee on Banking Supervision (2011), Progress report on Basel III implementation, Bank for International Settlements

6. Basel Committee on Banking Supervision (2010), Basel III: A global regulatory framework for more resilient banks and banking systems, Bank for International Settlements

7. Davis P.; Karim D. (2009), Macro-prudential regulation - the missing policy pillar, paper presented at the 6th Euro-frame Conference on Economic Policy Issues in the European Union

8. Delgado F.; Meza M. (2011), Developments in Financial Supervision and the Use of Macroprudential Measures in Central America, International Monetary Fund

9. Elliott D. (2010), Basel III, the Banks, and the Economy, The Brookings Institution

10. Galati, G.; Moessner R. (2011), Macro-prudential Policy - A Literature Review. Bank of International Settlements

11. Resti A. (2002), The new Basel capital accord structure, possible changes and micro-and macroeconomic effects, Centre for European Policy Studies

12. Resti A. (2004), The new Basel capital accord and the future of the European financial system rapporteurs, Centre for European Policy Studies

13. Unsal F. (2011), Capital Flows and Financial Stability: Monetary Policy and Macro-prudential Responses, International Monetary Fund

14. Woolford I. (2011), Implementation of Basel III capital adequacy requirements in New Zealand, Reserve Bank of New Zealand 